\begin{tabular}{|c|} 
ISSN = 1980-993X - doi:10.4136/1980-993X \\
www.agro.unitau.br/ambi-agua \\
E-mail: ambi-agua@agro.unitau.br \\
Tel.: (12) 3625-4116
\end{tabular}

\title{
Spectral mixture analysis for water quality assessment over the Amazon floodplain using Hyperion/EO-1 images \\ (doi:10.4136/ambi-agua.13)
}

\section{Conrado de Moraes Rudorff; Evlyn Márcia Leão de Moraes Novo; Lênio Soares Galvão}

\author{
Instituto Nacional de Pesquisas Espaciais - INPE \\ Caixa Postal 515 - 12245-970 - São José dos Campos - SP, Brasil \\ E-mail: \{cmr, evlyn, lenio\}@ltid.inpe.br
}

\begin{abstract}
Water composition undergoes complex spatial and temporal variations throughout the central Amazon floodplain. This study analyzed the spectral mixtures of the optically active substances (OASs) in water with spaceborne hyperspectral images. The test site was located upstream the confluence of Amazon (white water) and Tapajós (clear-water) rivers, where two Hyperion images were acquired from the Earth Observing One (EO-1) satellite. The first image was acquired on September 16, 2001, during the falling water period of the Amazon River. The second image was acquired on June 23, 2005, at the end of the high water period. The images were pre-processed to remove stripes of anomalous pixels, convert radiancecalibrated data to surface reflectance, mask land, clouds and macrophytes targets, and spectral subset the data within the range of $457-885 \mathrm{~nm}$. A sequential procedure with the techniques Minimum Noise Fraction (MNF), Pixel Purity Index (PPI) and n-dimensional visualization of the MNF feature space was employed to select end-members from both images. A single set of end-members was gathered to represent the following spectrally unique OASs: clear-water; dissolved organic matter; suspended sediments; and phytoplankton. The Linear Spectral Unmixing algorithm was applied to each Hyperion image in order to map the spatial distribution of these constituents, in terms of sub-pixel fractional abundances. Results showed three patterns of changes in the water quality from high to falling flood periods: decrease of suspended inorganic matter concentration in the Amazon River; increase of suspended inorganic matter and phytoplankton concentrations in varzea lakes; and increase of phytoplankton concentration in the Tapajós River.
\end{abstract}

Keywords: Hyperspectral remote sensing; spectral mixture analysis; phytoplankton; dissolved organic matter; suspended inorganic matter.

\section{Avaliação da qualidade da água na planície de inundação amazônica por meio de análise de mistura espectral de imagens do sensor Hyperion/EO-1}

\section{RESUMO}

A água distribuída pelos diversos ambientes na planície de inundação da Amazônia central passa por complexas variações espaciais e temporais na sua composição. O presente estudo analisou a mistura espectral de constituintes opticamente ativos (COAs) na água, usando imagens orbitais de sensor hiperespectral. A área de estudo localiza-se à montante da confluência dos rios Amazonas (água branca) e Tapajós (água clara), onde duas imagens Hyperion foram adquiridas a partir do satélite Earth Observing One (EO-1). A primeira 
imagem foi adquirida em 16 de setembro de 2001, durante o período de vazante do rio Amazonas. A segunda imagem foi adquirida em 23 de junho de 2005, no final do período de cheia. As imagens foram pré-processadas para remover faixas de pixels anômalos, converter dados calibrados de radiância para reflectância de superfície, aplicar máscara de alvos terrestres, nuvens e macrófitas, e limitar os dados ao intervalo espectral 457-885nm. Um procedimento seqüencial das técnicas Fração Mínima de Ruído (MNF), Índice de Pureza de Pixel (PPI) e visualização do espaço de atributos n-dimensional gerado entre as bandas MNF foi empregado para selecionar membros de referência a partir das duas imagens. Um conjunto único de membros de referência foi composto para representar os seguintes COAs, espectralmente distintos: água clara, matéria orgânica dissolvida, sedimentos em suspensão; e fitoplâncton. O Modelo Linear de Mistura Espectral foi aplicado a cada imagem Hyperion para mapear a distribuição espacial destes constituintes em termos das abundâncias fracionais sub-pixels. Os resultados demonstraram três padrões de mudanças na qualidade da água entre as situações de inundação nos períodos de cheia e de vazante: diminuição na concentração de matéria inorgânica em suspensão no rio Amazonas; aumento nas concentrações de matéria inorgânica em suspensão e fitoplâncton nos lagos da várzea; e aumento na concentração de fitoplâncton no rio Tapajós.

Palavras-chave: Sensoriamento remoto hiperespectral; análise de mistura espectral; fitoplâncton; matéria orgânica dissolvida; matéria inorgânica em suspensão.

\section{INTRODUCTION}

Natural waters are complex physical-chemical-biological media comprising living, nonliving, and once-living materials that may be present in aqueous solution or suspension. Climate and hydrology may cause major changes in water quality and in the ecological status of water. The annual flood pulse propagating throughout the Amazon Basin characterizes a monomodal hydrologic regime (Junk, 1997), which can be summarized, in terms of the water level of the floodplain-river system, into four important periods: low; rising; high; and falling. In the Central Amazon Floodplain, the water level of the Amazon River varies annually with the amplitude of around 7 to $6 \mathrm{~m}$. The maximum level is reached during the high water period between May and July, and the minimum level is reached during the low water period between November and December. Water properties respond to the flood pulse. At the beginning of the rising water level period, submerged organic material such as plant and animal detritus begins to decompose and the development of a great amount of macrophytes takes place near the margins of water bodies. During the high water level period, suspended matter with associated nutrients from the Amazon River are introduced into floodplain lakes and are deposited as the turbulence is reduced. Macrophyte continues to grow, since they are very efficient in retrieving the nutrients available in the water. This causes the nutrients to be less available for phytoplankton. In fact, the major events of phytoplankton blooms occur when macrophytes begin to decompose at the falling water level period. Also, during this period other environmental factors induce the development of phytoplankton blooms, such as more intensive solar illumination, favored by clearer skies, and re-suspension of sediments with nutrients deposited at the bottom of the lakes, favored by depth reduction and wind intensification. The level of connection of the mainstream with floodplain lakes decreases towards the low water period. Thus, the contribution of water from the river into the floodplain lakes decreases and lakes develop their own limnological characteristics. At low 
water a great portion of the floodplain area have turned from aquatic to terrestrial phase (Junk, 1997).

Human induced changes over the basin are causing water pollution which in turn threatens the ecology of the Amazon floodplain and the health of the riverside population. Pollutants in water include a wide spectrum of chemicals, pathogens, and physical chemistry or sensory changes. For instance, the disturbance and mobilization of large quantities of sediment into the water column during mining operations (Telmer et al., 2006) and soil erosion process associated to deforestation (Mainville et al., 2006) is contributing to fish mercury $(\mathrm{Hg}$ ) contamination. Pinheiro et al. (2006) observed that the Hg levels detected in exposed fish eating populations of the Tapajós River are above the World Health Organization acceptable levels. Organic wastes such as urban sewage and farm waste (specially from water buffalo and cattle ranching) impose high oxygen demands on the receiving water leading to oxygen depletion. Higher frequency of phytoplankton blooms can be associated with the increases of nutrient loadings that lead to eutrophication (Novo et al., 2006).

The significant spatial-temporal variability in the composition of Amazon floodplain water, derived from the ever-changing water level over a vast and diverse environment, makes the distinction between natural and human induced impacts over water quality extremely difficult. Also, traditional water quality monitoring techniques, based only on sporadic sampling over time and space, becomes ineffective for monitoring wide regions of the Amazon floodplain. Optical Remote sensing methods and technology have been largely considered and tested for water quality assessment. Along with the pure water molecules themselves, there are materials in water column, denominated Optically Active Substances (OASs), which interact with the light field. The main OASs in natural water are: phytoplankton; dissolved organic matter (DOM); and suspended inorganic matter (SIM). The optical properties of these substances are closely related to the water quality, and have been discussed in detail by several authors (Bukata et al., 2000; Dekker, 1993; Kirk, 1994). "Ocean color" sensors (e.g., SeaWiFS and MODIS) have not been suitable for inland water quality mapping due to spatial resolution constraints, and other "land" sensors (e.g., Landsat-7/ETM ${ }^{+}$ and CBERS-2/CCD) due to radiometric and spectral limitations.

In November 21, 2000, Hyperion was brought to the scientific community as the first orbital sensor to produce hyperspectral images of the terrestrial surface. It is transported on board of the Earth Observing One (EO-1) satellite, at a $705 \mathrm{~km}$ altitude orbit. The EO-1 satellite is part of the National Aeronautics and Space Administration (NASA) "New Millennium Program". This orbital platform was projected to evaluate the performance of new technologies and strategies that seek to improve satellite Earth observation for a wide range of applications. The key feature of Hyperion imagery is that it provides measurements of a near complete spectrum, from visible (VIS) to short wave infrared (SWIR) range, for each pixel (with $30 \mathrm{~m}$ spatial resolution) using narrow wavebands (with $10 \mathrm{~nm}$ spectral resolution). The Hyperion sensor was not designed for water applications, since its signal-tonoise ratio (SNR) is relatively low (160:1). In spite of that, preliminary studies have provided encouraging results showing its applicability to coastal water mapping (Vittorio and Dekker, 2003). Therefore we found it worthy to assess applications with Hyperion images to study the composition of inland Amazonian waters.

Hyperspectral imagery presents a number of opportunities for interpretation and analysis (Aspinall et al., 2002). The Linear Spectral Unmixing (LSU) algorithm has been widely used in hyperspectral image analysis to determine the pixel composition by modeling the abundances of spectrally unique substances, denominated "end-members" (Adams et al., 
1986). Novo and Shimabukuro (1994) proposed a spectral mixture analysis of OASs for inland waters, to reduce high spectral resolution data to images where the fractional abundance of a given substance is readily observed. The success of this approach will depend on the availability of pure end-members and the linearity of the interaction between the optical components of the mixture. Preferably, end-members should be obtained from the image under analysis once the reflectance spectra measured in laboratory can not account for undesirable environmental and instrumental signal variation that interferes in an orbital sensor measurement (Kruse et al., 2003).

The present study was carried out to evaluate the use of Hyperion images to map water constituents in the Amazon floodplain, by determining the fractional abundances of clearwater, DOM, SIM and phytoplankton, using a LSU algorithm.

\section{MATERIAL AND METHODS}

The experimental site is situated just upstream the confluence of Amazon and Tapajós rivers, near the city of Santarém-PA, Brazil (Figure 1). An archived Hyperion image, acquired on September 16, 2001, was identified within the USGS EROS Data Center, and showed a wide range of multi-componental mixtures along the floodplain waters. In the hydrologic context, this image represented the falling water period. A second Hyperion image asked to be programmed by our team and was successfully collected over the same site on June 23, 2005, at the end of the high water period.

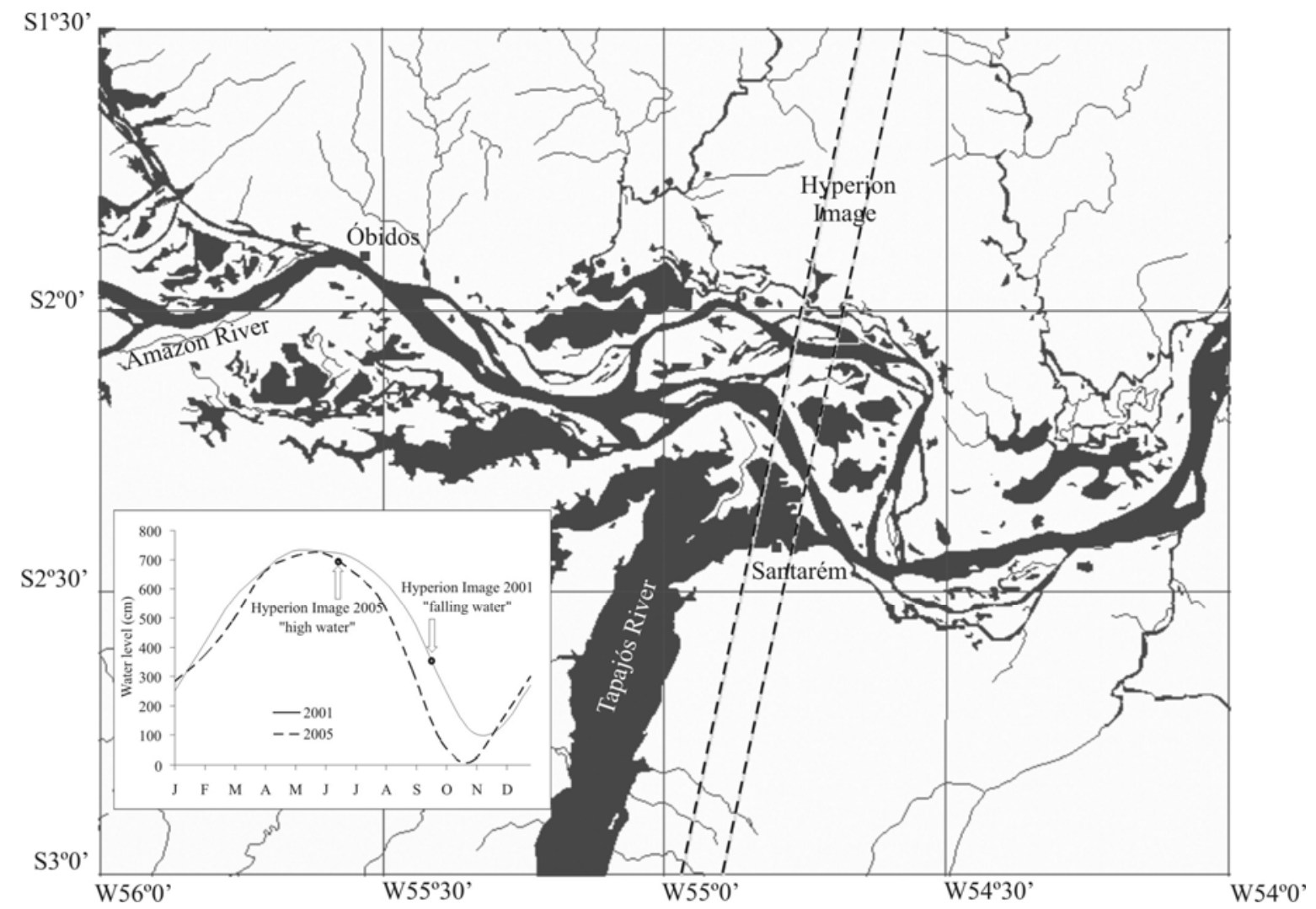

Figure 1. Location map of the study area. The parallel dashed lines present the swaths of the Hyperion images collected over the area. Hydrographs registered for the Amazon River at ÓbidosPA, over the years 2001 and 2005, are shown in the inset. 
The Hyperion images were preprocessed according to the following steps: de-striping to remove anomalous pixels (Han et al., 2005); correction of radiance-calibrated data to surface reflectance, using the Atmospheric CORrection Now (ACORN) model-based software which uses licensed MODTRAN4 technology (AIG, 2001); building and applying a mask to remove land, clouds and macrophytes targets; and spectral range subsetting within the range 457$885 \mathrm{~nm}$.

The main concept of spectral mixture analysis to study the water composition is that the reflectance measured at a given pixel is represented by the sum of end-members, which represent each OAS, weighted by its relative proportion or abundance (Novo; Shimabukuro, 1994)

$$
R_{p i}=\sum f_{j} r_{i j}+\varepsilon_{i}
$$

where, for a given pixel $p, R_{p i}$ is the water remote sensing reflectance of the $i^{t h}$ band, $j$ represents the end-member for a certain OAS, $f_{j}$ is the fractional abundance of the $j^{\text {th }}$ endmember, $r_{i j}$ is the $j^{\text {th }}$ end-member reflectance of the $i^{\text {th }}$ band, and $\varepsilon_{i}$ is the error in the $i^{\text {th }}$ waveband.

Thus, the first step in the spectral mixture analysis is to select end-members for the model. A semi-automated procedure was used for the end-member extraction directly from the Hyperion images, as proposed by Kruse et al. (2003). This procedure is implemented in the ENVI image analysis software, and includes: spectral data reduction using the Minimum Noise Fraction (MNF) transformation (Green et al., 1988; Kruse et al., 1993); spatial data reduction using the Pixel Purity Index (PPI) (Kruse et al., 1993); and end-member selection using a n-Dimensional Visualizer (Kruse et al., 1993). Once the end-members were selected they were identified according to their spectral properties. As the two Hyperion images were acquired presenting much different conditions of water quality, it was considered that the endmembers selected from each image should be combined to form one unique set of endmembers to represent clear-water and waters dominated, individually, by each OAS: DOM, SIM, and phytoplankton. This strategy was adopted to increase the availability of 'pure' endmembers.

The inversion process of equation (1) determines the fractional abundance of each endmember. The fractional end-member abundance calculated for each pixel of the hyperspectral image is then spatially reassembled to produce separate images. At last, the fractional abundances $(f)$ of clear-water and the OASs were mapped applying LSU to each Hyperion image.

A field campaign was carried out between June 23 and 29, 2005 to provide ground truth data, in order to help explain the results obtained from the analysis of the Hyperion image acquired on June 23, 2005. Water samples and simultaneous radiometric measurements were collected at 43 stations distributed over the water bodies in the study site. A Global Positioning System (GPS) was used to register their geographic position.

A Spectron Engineering SE-590 spectroradiometer was used to collect radiance upwelling from the water with a barium sulphate painted panel serving as reference. The spectroradiometer acquires data in the spectral range from 368.4 to $1113.7 \mathrm{~nm}$. For our study, data from 445.3 to $896.4 \mathrm{~nm}$ (153 channels) were used for comparison with Hyperion spectral reflectance data, in order to check for the occurrence of any important variations of water inherent optical properties along the seven days period of the field campaign. 
The bidirectional reflectante factor (in \%) was calculated by using the following equation:

$$
R_{\text {water }}(\lambda)=\frac{D N_{\text {water }}(\lambda)}{D N_{\text {panel }}(\lambda)} \times R_{\text {panel }}(\lambda),
$$

where $R_{\text {water }}(\lambda)$ is the bidirectional reflectante factor of the water, $D N_{\text {water }}$, is the raw digital number measured over the water, $D N_{\text {panel }}$ is the raw digital number measured over the reference panel, $R_{\text {panel }}$ is the bidirectional reflectante factor of the reference panel, and $\lambda$ is the wavelength.

Each day of the field campaign, sampling was carried out between $10 \mathrm{~h} 00 \mathrm{~m}$ and $14 \mathrm{~h} 00 \mathrm{~m}$ (local time), in order to minimize changes in measurement conditions due to variation of the Sun's illumination geometry. The sensor was positioned over each sampling station with orientation of $90^{\circ}$ solar azimuth, $45^{\circ}$ inclination and approximately $2 \mathrm{~m}$ height of above the water.

Assuming that the portion of the water column with the major influence over the water upwelling radiance detected by the sensor remains close to the subsurface, water samples of five liters were collected at $0.5 \mathrm{~m}$ depth below the surface at each station immediately after the field spectral measurements were made. The water samples were filtered at the field site and adequately conserved for transportation, following the specific orientations of each method of analysis. After a period of 18 days, the concentrations (C) of chlorophyll- $a$ (Chl- $a$ ) in $\mu \mathrm{g} \cdot \mathrm{l}^{-1}$ (Nush, 1980), suspended inorganic matter (SIM) in $\mathrm{mg} \cdot \mathrm{l}^{-1}$ (Wetzel e Likens, 1991), and dissolved organic carbon (DOC) in ppm (APHA, 1998) were determined in laboratory.

Geometric correction was performed on a true color composition Hyperion image (RGB: $640 ; 549 ; 457 \mathrm{~nm}$ ), by selecting ground control points (GCPs) from a Landsat/TM orthorectified image, and applying a second degree polynomial warp with the nearest neighbor resampling method. The inverse geometric model was used to match the ground sampling stations to their correspondent location in the Hyperion image. The mean values of the fractional end-member abundance bands were computed for a $4 \times 4$ pixels window, centered at the position of each sampling station. Statistical relationships were determined between the measured in situ concentration of OASs variables and the respective fractional end-member abundances.

The Hyperion image acquired on September 16, 2001 yields an important contribution by increasing available Hyperion data for end-member selection. However, despite the fact that there was no ground truth data correspondent to this period, this image was also analyzed using the LSU algorithm, in order to demonstrate somewhat of the potential of carrying out temporal analysis through this approach. In which case, by attempting only to seasonal changes, the image acquired on June 23, 2005 represented the flood situation of high water period and the image acquired on September 16, 2001 represented the flood situation of falling water period.

\section{RESULTS AND DISCUSSION}

\subsection{End-member selection}

There will always be mixtures of dissolved or suspended materials present in any natural water body, thus, the desired conceptual 'pure' end-members for OASs in the water is not accessible. In this case, the LSU results will not lead to a complete virtual separation of the fractions; they will rather indicate a relative proportion of each end-member, in which the relationship with the actual concentration of a certain OAS will be stronger according to its 
reflectance spectral dominance. The end-members that resulted from the procedure of selection described in section 2 represented the pixels that were most spectrally dominated by each individual OAS. The clear-water and DOM end-members (Figure 2) were extracted from June 23, 2005 Hyperion image, and the SIM and phytoplankton end-members (Figure 2) were extracted from September 16, 2001 Hyperion image. Clear-water presents very low concentrations of OASs; consequently, the spectral reflectance is low and shaped according to the optical properties of pure water molecules, which produce an exponential increase of absorption towards longer wavelength and scattering towards shorter wavelength, over the VNIR. Dissolved organic matter increases the water absorption exponentially towards shorter wavelengths (Kirk, 1994) and produces fluorescence in the red and NIR bands. The phytoplankton spectrum shows a prominent reflectance peak in the green region, representing the minimal aggregate absorption of all algal pigments. The red band of chlorophyll (Chl) absorbance at $670-675 \mathrm{~nm}$ was prominent and sensitive to both pigment absorption and aggregate scattering by algae and other particles. A pronounced absorption feature at about 620-630 nm was present. A second prominent reflectance peak was observed near $700 \mathrm{~nm}$, a wavelength longer than the red absorbance band of algal pigments and lower than the region of maximal water absorbance. Although Chl fluorescence, centered near $685 \mathrm{~nm}$, contributes to this feature, the majority of the radiance measured in this peak is due to scattering from algal cells and other particulate matter (Dekker, 1993). The spectrum of water dominated by SIM is characterized by an increase in reflectance through all the VNIR spectral range, but more particularly towards the $580-680 \mathrm{~nm}$ range (Novo et al., 1991).

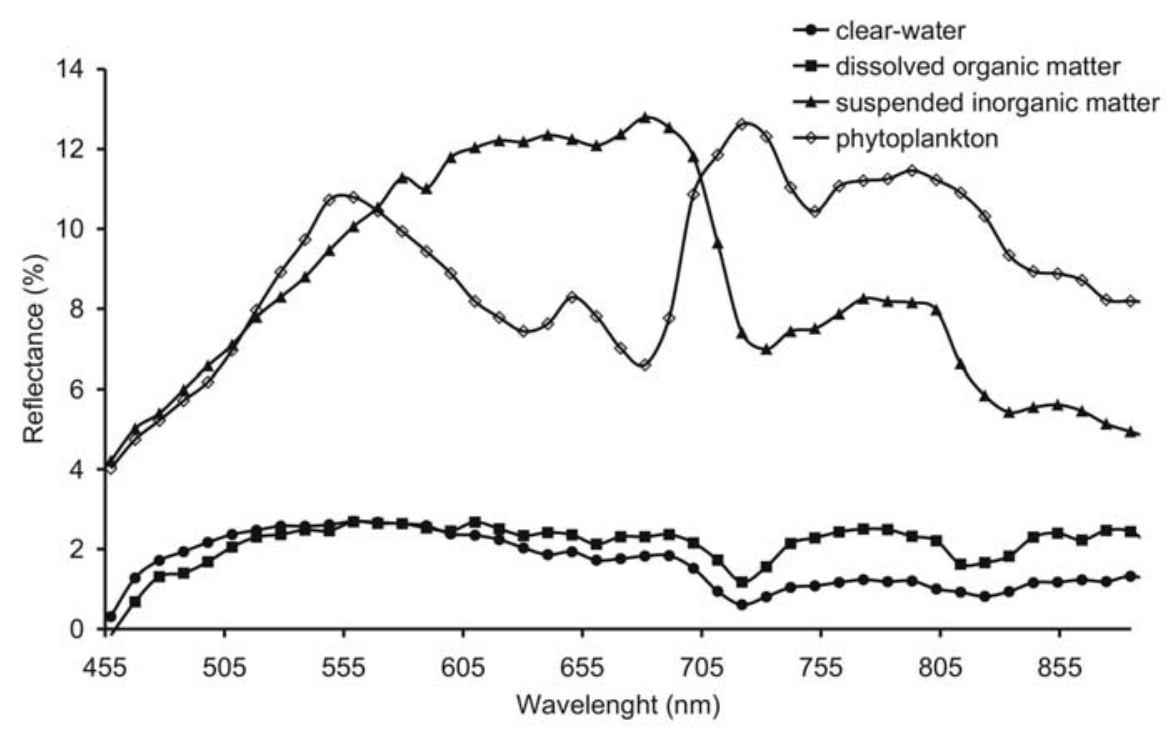

Figure 2. Hyperion end-members spectra of waters dominated by optically active substances.

\subsection{Relationships between ground sampled concentrations and Hyperion mapped abundances of optically active substances at high water period}

Image data was acquired instantaneously over the study site by the synoptic view of the Hyperion detectors. However, field measurements could not be taken simultaneously at all sampling stations, and therefore they were subjected to small but inevitable environmental instabilities along the period of the field campaign, especially due to wind once local precipitation did not occur. A good satisfactory match between orbital (Hyperion) and field (SE-590) data sets, in the range from 450 to $900 \mathrm{~nm}$, was observed by means of two 
comparison approaches: visual analysis of reflectance spectra for each sampling station; and correlation analysis $(n=43$ sampling station) between reflectance bands and concentrations of the OASs. These comparisons allowed verifying that it was possible to assume that the water inherent optical properties remained stable during the seven days of the field campaign period, providing confidence for the subsequent analysis of the Hyperion image acquired on June 23, 2005. Such stable characteristic for high water period was also observed by Barbosa (2005).

Figure 3 shows the relationships between fractional abundances $(f)$, derived from spectral mixture analysis of Hyperion reflectance data, and concentration of water OASs in different environments. The concentration of dissolved organic carbon $\left(C_{\mathrm{DOC}}\right)$ does not vary significantly between turbid water from the Amazon River and water with low turbidity from floodplain lakes (Figure 3a). The increase of $C_{\text {SIM }}$ causes the reduction of $f_{\text {DOM }}$ in spite of having an effective variation of $C_{\mathrm{DOC}}$ in water. For this reason, the quantification of DOM spatial variation by means of the spectral mapping was not accomplished. The clear-water samples (Tapajós River) are set apart by presenting low $C_{\mathrm{DOC}}$, and were correctly determined with $f_{\text {DOM }}$ close to zero.

As phytoplankton was not abundant during the high water level period, it had a relatively small effect on water spectral characteristics. As a consequence, the maximum value of fractional phytoplankton end-member abundance $\left(f_{\text {phytoplankton }}\right)$ was 0.08 , which corresponds to $C_{\mathrm{Chl}-a}=48 \mu \mathrm{g}^{-1}$. However, mapping results of $f_{\text {phytoplankton }}$ still presented a positive correlation with $C_{\mathrm{Chl}-a}(r=0.515 ; p$-value $=0.000)$. The algorithm provided better results in waters characterized by low turbidity. Clear-water (Tapajós River) and water with high loads of DOM, present in small floodplain lakes surrounded by vegetation, both with low $C_{\mathrm{Chl}-a}$, were mapped with $f_{\text {phytoplankton }}$ close to 0 (Figure $3 \mathbf{b}$ ). Triangle marks in Figure $3 \mathbf{b}$ indicate that SIM-rich water (Amazon River) caused the reduction of $f_{\text {phytoplankton }}$ towards negative values.

The reflectance of SIM is dominant over all the others OASs in water. In fact, the LSU showed the best potential to estimate the abundance of SIM $\left(f_{\mathrm{SIM}}\right)$. Mapping results for fractional SIM end-member abundance $\left(f_{\text {SIM }}\right)$ showed high correlation with the $C_{\text {SIM }}$ measured on the ground sampling stations $(r=0.75 ; p$-value $=0.000)$. A nonlinear effect over the spectral mixture of SIM with the others OASs was observed. As a result, $f_{\text {SIM }}$ values determined by the LSU algorithm were not directly proportional to the $C_{\mathrm{SIM}}\left(\mathrm{mg} \mathrm{l}^{-1}\right)$ measured in situ. The negative $f_{\text {SIM }}$ estimates over the sampling stations were coincident with those stations that presented high $C_{\mathrm{Chl}-a}$. Low turbidity waters were correctly mapped by presenting $f_{\text {SIM }}$ close to 0 (Figure 3c). The relationship presented in Figure $3 \mathbf{c}$ indicates that, in the abundance range between 0 and 0.5 , there is a quasi-linear increase in $C_{\text {SIM }}$ up to $15 \mathrm{mg} \mathrm{l}^{-1}$. For $f_{\text {SIM }}$ larger than 0.5 , the increase of actual $C_{\text {SIM }}$ becomes exponential.

The Linear Spectral Unmixing (LSU) algorithm assumes that the sum of all fractions should be equal to 1 . Therefore, in cases of nonlinearities, such as observed with the OASs mixtures in inland waters, when the model overestimates one fraction, any of the other fractions may have to be underestimated in order to compensate for the overestimation. This explains negative or over 1 estimates of end-member abundances $\left(f_{j}\right)$ that were observed from the results.

\subsection{Temporal Variability}

The variation of water quality condition was analyzed using the information derived from the Hyperion images of high and falling water periods. Figure 4 shows true color composites of the two Hyperion scenes $(\mathrm{a}, \mathrm{g})$, the fractional abundance images of the water 
constituents (b to e; and $\mathrm{h}$ to 1 ), and the root mean square (RMS) error images ( $\mathrm{f}$ and $\mathrm{m}$ ) resultant from the spectral mixture model.
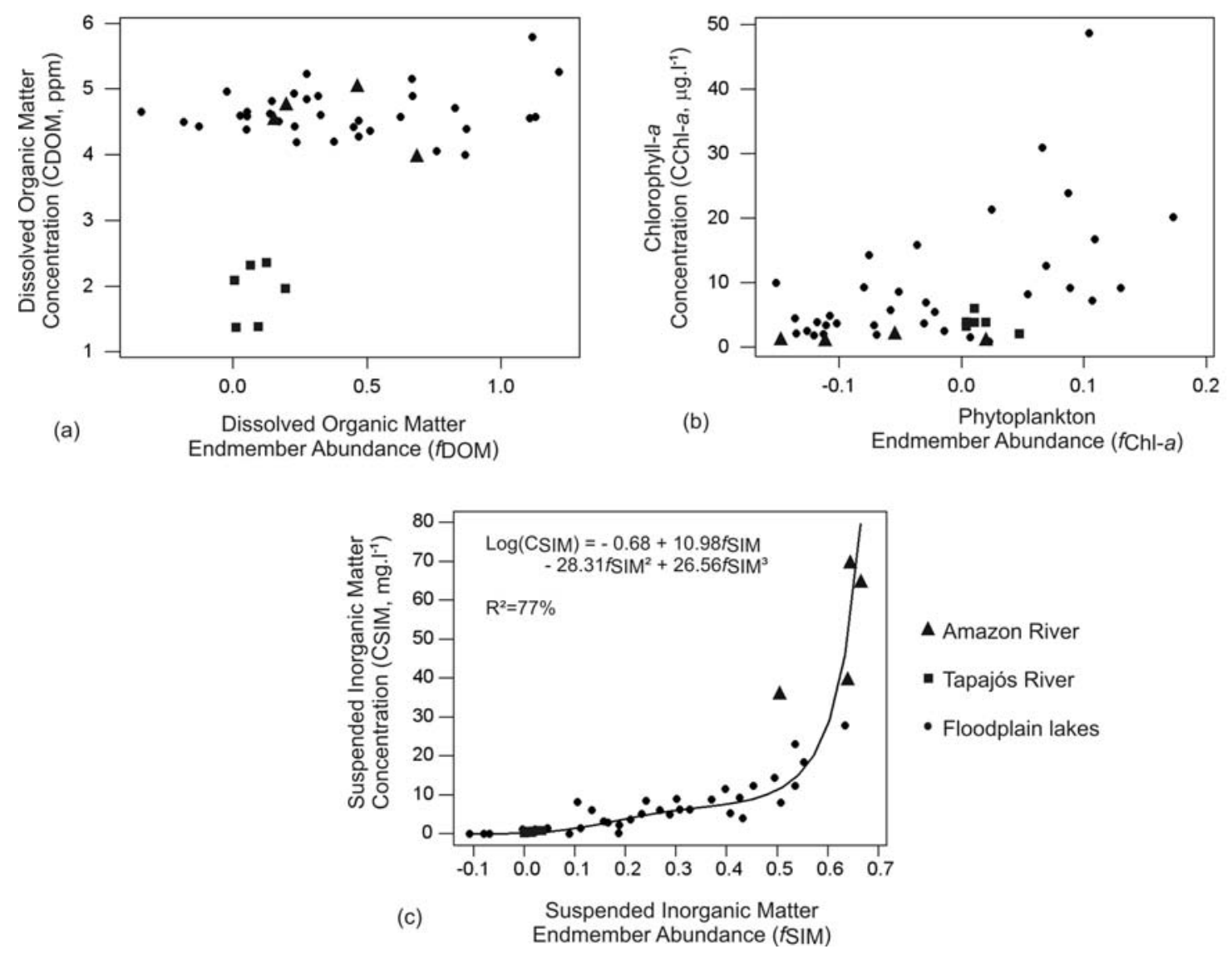

Figure 3. Relations between: (a) $C_{\mathrm{DOC}}$ and $f_{\mathrm{DOM}}$; (b) $C_{\mathrm{Chl}-a}$ and $f_{\text {phytoplankton}}$; and (c) $C_{\mathrm{SIM}}$ and $f_{\text {SIM. }}$.

The RMS error image presented in Figure $\mathbf{4 m}$ showed larger uncertainties over lakes with mixture of high concentrations of algae and SIM. The dominant influence of SIM reflectance, not only detracts the evidences of phytoplankton Chl- $a$ features over the spectra, but also produces an opposite spectral behavior on the red bands, where Chl- $a$ acts as an absorber and SIM as a scatterer. This effect led the LSU to map $f_{\text {phytoplankton with negative }}$ values over waters with strong SIM influence.

The low reflectance signal of water is highly affected by undesired fluxes of radiance also captured by the sensor (Bukata et al., 2000), which introduce uncertainties to the results. For instance, the high water RMS error image (Figure 4f) shows larger uncertainties over regions affected by haze, mainly concentrated at the north of Tapajós River and south of the Amazon River. The presence of haze seemed to affect the values of $f_{\text {phytoplankton, causing a false }}$ apparent increase. Even though the Hyperion data were transformed from radiance to surface reflectance, the atmospheric conditions were more rigorous during the image acquired at high water, which contaminated part of the image with haze that could not be totally removed by the atmospheric correction procedure.

Generally, considering the fractional abundance and RMS error images resulted from LSU mapping and the relations observed in section 3.2, we conclude that: SIM presented the best potential for estimation; $f_{\text {phytoplankton }}$ mapped for both periods showed important features over the images, capable of indicating the spatial distribution of Chl- $a$; $f_{\text {clear-water }}$ and $f_{\mathrm{DOM}}$ presented reliable results only over non turbid waters, where the LSU determined values of 
either $f_{\text {clear-water }}$ or $f_{\text {DOM }}$ close to 1 and abundance values of the others OASs close to 0 . Over water with low turbidity, the LSU abundance results $f_{\text {clear-water }}$ and $f_{\text {DOM }}$ were very sensitive to slight reflectance variation, controlled by: water molecules scattering and DOM absorption, in the blue bands; and water molecules absorption and DOM fluorescence, in the red and NIR bands. Over turbid waters, the spectral influence of SIM and phytoplankton caused total uncertainties on the results of $f_{\text {clear-water }}$ and $f_{\text {DOM }}$.

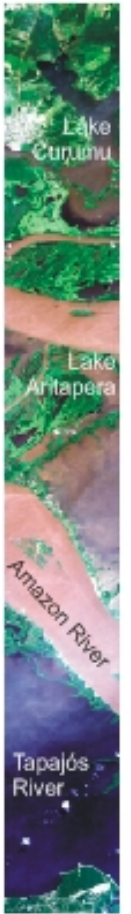

(a)

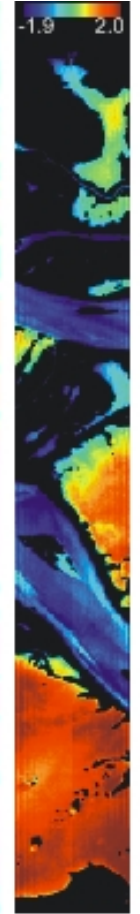

(b)

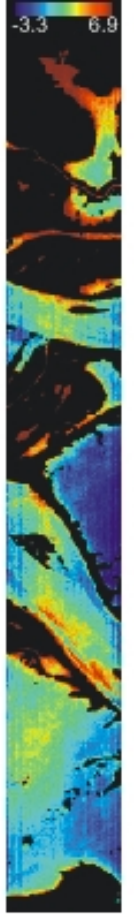

(c)

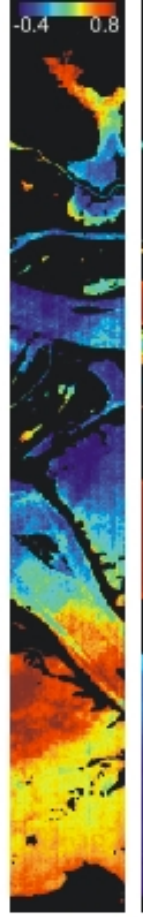

(d)

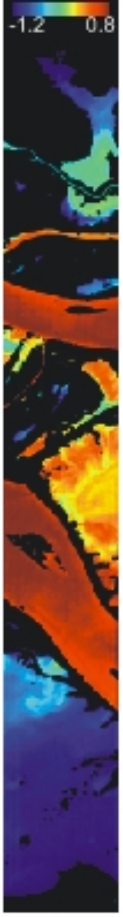

(e)

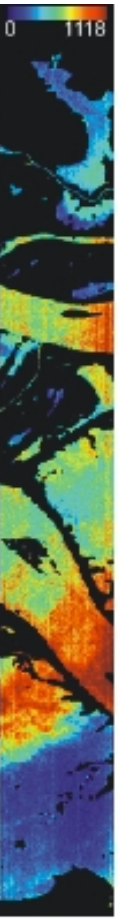

(f)

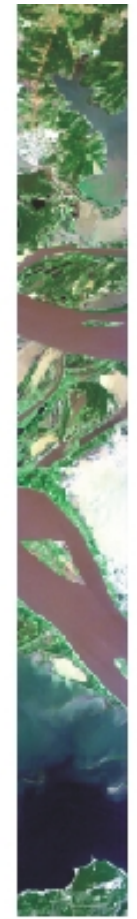

(g)

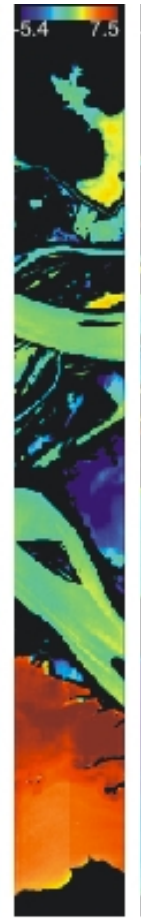

(h)

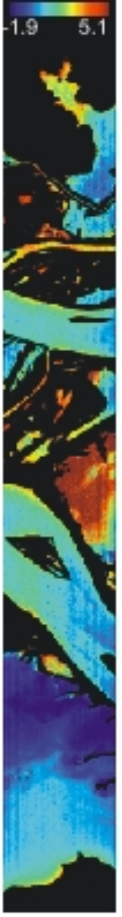

(i)

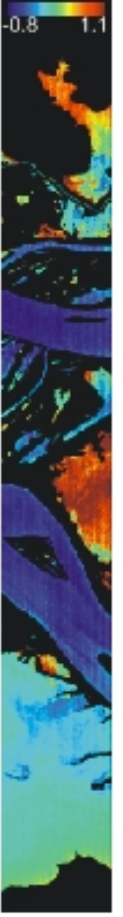

(j)

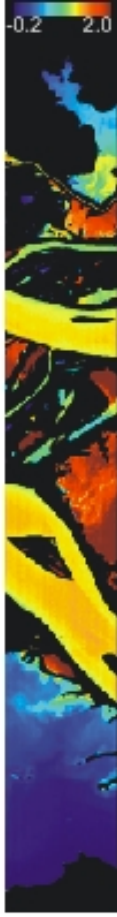

(I)

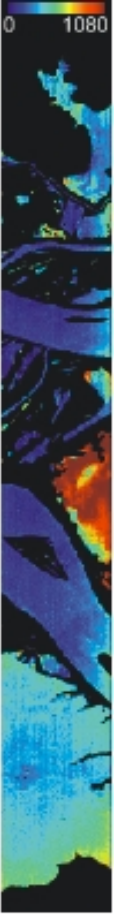

(m)

Figure 4. True color composites (RGB: 640; 549; 457nm) of Hyperion images collected on: (a) June 23, 2005; and (g) September 16, 2001. Fractional end-member abundance results presented as color images: (b) and (h) $f_{\text {clear-water }}$; (c) and (i) $f_{\text {DOM }}$; (d) and (j) $f_{\text {phytoplankton; }}$ (e) and (l) $f_{\text {SIM }}$. Root mean square (RMS) error images are presented in (f) for June 23 and in (m) for September 16.

In order to discuss the effects of reflectance spectral-temporal variation over $f_{\text {SIM }}$ and

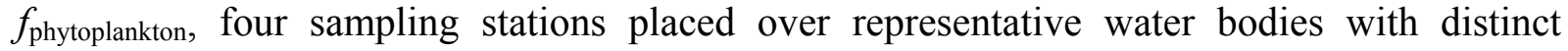
physicochemical and hydrological conditions were selected over the study area: Tapajós River; Amazon River; Lake Aritapera; and Lake Curumu. Figure 4a shows the location of these water bodies. Figure 5 shows the mean reflectance spectra obtained from 4 x 4 pixels windows and the respective calculation of $f_{\mathrm{SIM}}$ and $f_{\text {phytoplankton, for high and falling water }}$ periods. The data extracted for each image was geographically correspondent.

The Tapajós River is a large tributary of the Amazon. The euphotic zone in the Tapajós is deep, but these clear-waters are considered poor in nutrients when compared to the Amazon River (Junk, 1997). Over the Tapajós, at both flood periods, the model determined values of $f_{\text {clear-water }}$ close to 1 and fractional abundances of the OASs $\left(f_{\mathrm{DOM}} ; f_{\mathrm{SIM}}\right.$; e $\left.f_{\text {phytoplankton }}\right)$ close to 0 . This was expected since the concentrations of OASs in clear-waters are low. The reflectance spectra and the calculated abundances both evidenced an increase of algae production in the Tapajós River towards the falling water period (Figure 5a).

The Amazon is the main river of the floodplain. The water reflectance of the Amazon River is permanently dominated by SIM. Thus, the model showed good efficiency by determining values of $f_{\text {SIM }}$ higher than 0.5 and $f_{\text {phytoplankton }}$ close to 0 for pixels placed over the 
Amazon River during both water level periods (Figure 5b). The water of the Amazon River has nitrogen limitations (Junk, 1997), shallow euphotic zone, and turbulence. These factors limit the growth of phytoplankton throughout the seasons. According to Barbosa (2005), concentration of SIM in the Amazon River at the falling water period is around $20 \mathrm{mg}^{-1}$. The concentration of SIM measured at the field during high water was $64.33 \mathrm{mg}^{-1}$. From these values it is possible to consider a variation of around $40 \mathrm{mg} \mathrm{l}^{-1}$ in $C_{\mathrm{SIM}}$ between the two periods. This resulted in a higher $f_{\text {SIM }}$ mapped for high water. The concentration of SIM at high water is more than two times higher than at falling water period, but $f_{\text {SIM }}$ observed for high (0.66) and falling (0.58) water periods do not demonstrate this same direct proportion. This can be explained by the variation of the inorganic and organic fraction of the total suspended matter composition observed between these periods (Barbosa, 2005), as well as the nonlinear effects between $f_{\text {SIM }}$ determined by LSU and the actual $C_{\text {SIM }}$ (Figure 3c). In fact, the spectra measured over Amazon water during high water presented higher reflectance values in, practically, the whole spectral range, except at wavelengths lower than $510 \mathrm{~nm}$. This absorption effect is most likely to be associated with the presence of suspended organic matter and dissolved organic matter adsorbed to the suspended particles (Dekker, 1993; Kirk, 1994).

Lake Aritapera is located in the interior of an island in the Amazon River. The fractional abundance of suspended inorganic matter determined for this lake was 0.55 during high water and 1.01 during falling water. This result agrees with the physical characteristics of this lake and the spectral variation observed from the images, evidencing conditions of high $C_{\text {SIM }}$ during the falling water period. The concentration of SIM becomes higher over shallow regions of the floodplain lakes as the water level falls. The gradual increase of $C_{\text {SIM }}$ causes reflectance elevation over the VIS and IVP spectral range. However, this occurs in a nonlinear manner: at a certain point of transition from high $C_{\text {SIM }}$ to muddy water or wet soil, the increase upon the reflectance saturates over the VIS but continues over the IVP due to the reduction of water absorption (the spectral response becomes similar to a soil spectrum). This brings severe complications to a linear spectral mixture analysis, because phytoplankton cells also produce light scattering in the IVP range. Hence, the increase in $f_{\text {phytoplankton }}$ mapped for this lake during the falling period is uncertain (Figure 5c). As mentioned before, the RMS error image presented greater uncertainties in shallow water lakes.

The Hyperion images show important spectral variability between high and falling water periods over Lake Curumu. During high water, the condition of low flow within the lake favors deposition resulting in water with low turbidity but with high concentration of DOM. The concentration of SIM increases towards the entrances of incoming water from the Amazon River. Over Lake Curumu, where this situation was observed, the LSU presented 0.31 for $f_{\text {SIM }}$ and negative values for $f_{\text {phytoplankton. }}$ A phytoplankton bloom was observed at the moment of the acquisition of the falling water Hyperion image, and the LSU showed 0.12 for $f_{\text {SIM }}$ and 0.51 for $f_{\text {phytoplankton }}$ (Figure 5d). According to the geomorphological characteristics of this lake, $\mathrm{C}_{\mathrm{SIM}}$ is actually expected to increase towards falling water, instead of decreasing as indicated by comparing the values of $f_{\mathrm{SIM}}$ determined for the two periods. This can be explained by the fact that at falling water the phytoplankton bloom occurred close to the surface and dominated the reflectance signal detected by the remote sensor, while SIM distributed itself more homogeneously along the water column with higher concentration towards the bottom. 
RUDORFF, C. M.; NOVO, E. M. L. M; GALVÃO, L. S. G. Spectral mixture analysis for water quality assessment over the Amazon floodplain using Hyperion/EO-1 Images. Ambi-Agua, Taubaté, v. 1, n. 2, p. 6579, 2006. (doi:10.4136/ambi-agua.13)
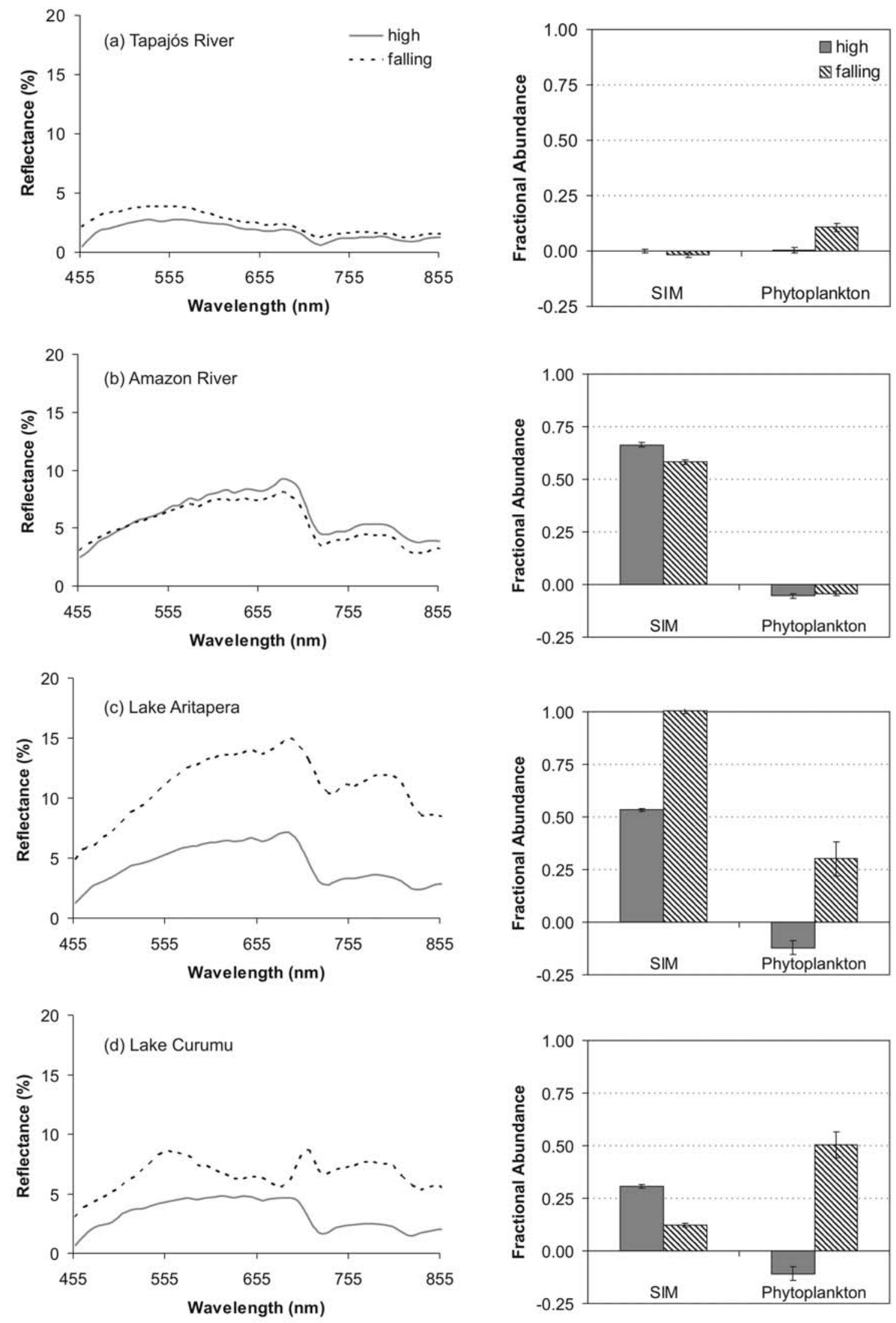

Figure 5. Temporal variability of reflectance, SIM and phytoplankton end-member abundances calculated for selected water bodies over the floodplain. 


\section{CONCLUSIONS}

The variation of water composition in the central Amazon floodplain is intense along the flood pulse periods. Hence, the approach of "key" spectral end-member selection from Hyperion data of both periods included in the analysis (high and falling water), favored for a greater availability of pixels dominated by clear-water and each individual optically active substance (OAS): suspended inorganic matter (SIM); dissolved organic matter (DOM); and phytoplankton. End-members obtained directly from the images under analysis allowed the removal of undesirable environmental and instrumental signal variations that may have affected Hyperion variations. However, the LSU algorithm could not lead to a complete virtual separation of the end-member fractions, once there is always mixtures of OASs present in any end-member pixel sensored over a natural water body. Relative proportion of each end-member was mapped and represented by the respective fractional abundance $(f)$ band, for which the relationship with the actual concentration of a certain OAS was stronger according to the spectral dominance of the substance.

From the analysis carried out with a Hyperion image acquired on 23 September, 2005 and ground truth data, we were able to conclude that the reflectance of suspended inorganic matter (SIM) was dominant over all the others OASs in water, and the LSU showed the best potential to estimate the concentration (C) of SIM. However, the relationship obtained between $f_{\text {SIM }}$ and $C_{\text {SIM }}$ was a polynomial expression, evidencing a nonlinear behavior for the spectral mixture of OASs in inland waters. The increase of $C_{\text {SIM }}$ caused reduction over $f_{\text {DOC }}$, in spite of having an effective variation of $C_{\mathrm{DOC}}$ in water, and for this reason the quantification of $C_{\mathrm{DOC}}$ spatial variation by means of the LSU mapping was not accomplished. Even though a well adjusted model was not reached with the mapping results of $f_{\text {phytoplankton }}$ and $C_{\mathrm{Chl}-a}$, a significant positive correlation was observed and the $f_{\text {phytoplankton }}$ bands obtained showed important features over the image, capable of indicating the spatial distribution of Chl- $a$ occurrence. Finally, the RMS error image showed considerably good results over areas of homogeneous water masses and increasingly large uncertainties over areas with intensive mixtures with high concentrations of OASs.

Three distinct general tendencies of water composition variation from high to falling flood periods were observed from the results of Linear Spectral Unmixing of two temporal Hyperion images: increase of suspended inorganic matter and phytoplankton concentrations, in varzea lakes; increase of phytoplankton concentration, in the Tapajós River; and decrease of suspended inorganic matter concentration in the Amazon River. Although, the results presented uncertainties derived from the nonlinear behavior of light interactions among the optically active substances in the multicomponental waters found in the study site, the linear spectral mixture analysis raised important evidences that improved the understanding of the spatial-temporal dynamics of this complex aquatic environment.

\section{ACKNOWLEDGMENTS}

Conrado M. Rudorff thanks CAPES for the scholarship funding that was offered during two years of Remote Sensing Master Course at INPE, where the research that originated this article took place. The authors thank GEOMA-MCT program for financial support of this research. The authors also thank NASA/LBA-Ecology for image acquisition and field support. 


\section{REFERENCES}

ADAMS, J. B.; SMITH, M. O.; JOHNSON, P. E. Spectral mixture modeling: a new analysis of rock and soil types at the Viking Lander 1 site. Journal of Geophysical Research, St. Louis, v. 91, p. 8098-8112, 1986.

AMERICAM PUBLIC HEALTH ASSOCIATION. Standard methods for the examination of water and wastewater. 20 ed. Washington: APHA, 1998.

ANALYTICAL IMAGING AND GEOPHYSICS. ACORN user's guide: stand alone version. Boulder, AIG, 2001. 64p.

ASPINALL, R. J.; MARCUS, W. A.; BOARDMAN, J. W. Considerations in collecting, processing, and analysing high spatial resolution hyperspectral data for environmental investigations. Journal of Geographical Systems, Berlin, v. 4, n. 1, p. 15-29, 2002.

BARBOSA, C. C. F. Sensoriamento Remoto da dinâmica de circulação da água do sistema planície de Curai / rio Amazonas. 281f. 2005. Tese (Doutorado em Sensoriamento Remoto) - Instituto Nacional de Pesquisas Espaciais, São José dos Campos, 2005.

BUKATA, R. P.; JEROME, J. H.; KONDRATYEV, K. Y. A.; POZDNYAKOV, D. V. Optical properties and remote sensing of Inland and Coastal Waters. Boca Raton: CRC Press LLC, 2000. 362p.

DEKKER, A. G. Detection of optical water quality parameters for eutrophic waters by high resolution remote sensing. 222f. 1993. Tese (Doutorado em Sensoriamento Remoto) - University of Amsterdam, Amsterdam, 1993.

GREEN, A. A.; BERMAN, M.; SWITZER, B.; CRAIG, M. D. A transformation for ordering multispectral data in terms of image quality with implications for noise removal. IEEE Transactions on Geoscience and Remote Sensing, Piscataway, v. 26, n. 1, p. 65-74, 1988.

HAN, T.; GOODENOUGH, D. G.; DYK, A.; LOVE, J. Detection and correction of abnormal pixels in hyperion images. In: IEEE GEOSCIENCE AND REMOTE SENSING SYMPOSIUM (IGARSS), 2002, Toronto. Proceedings... Ontario: IEEE International, 2005. p. 1327-1330. Disponível em: <http://ieeexplore.ieee.org>. Acesso em 21 out. 2005 .

JUNK, W. J. The central Amazon floodplain. Berlin: Springer, 1997. 525p.

KIRK, J. T. O. Light and photosynthesis in aquatic ecosystems. Cambridge: University Press, 1994. 525p.

KRUSE, F. A.; BOARDMAN, J. W.; HUNTINGTON, J. F. Comparison of airborne hyperspectral data and EO-1 Hyperion for mineral mapping. IEEE Transactions on Geoscience and Remote Sensing, Piscataway, v. 41, n. 6, p. 1388-1400, 2003.

KRUSE, F. A.; LEFKOFF, A. B.; BOARDMAN, J. W.; HEIDEBRECHT, K. B.; SHAPIRO, A. T.; BARLOON, P. J. et al. The spectral Image-Processing System (Sips): interactive visualization and analysis of imaging spectrometer data. Remote Sensing of Environment, New York, v. 44, n. 2/3, p. 145-163, 1993. 
MAINVILLE, N.; WEBB, J.; LUCOTTE, M.; DAVIDSON, R.; BETANCOURT, O.; CUEVA, E. et al. Decrease of soil fertility and release of mercury following deforestation in the Andean Amazon, Napo River Valley, Ecuador. Science of the Total Environment, [S.1.], v. 368, n. 1, p. 88-98, 2006.

NOVO, E. M. L. M.; SHIMABUKURO, Y. E. Spectral mixture analysis of inland tropical waters. International Journal of Remote Sensing, London, v. 15, n. 6, p. 1351-1356, 1994.

NOVO, E. M. L. M.; STEFFEN, C. A.; BRAGA, C. Z. F. Results of a laboratory experiment relating spectral reflectance to total suspended solids. Remote Sensing of Environment, New York, v. 36, n. 1, p. 67-72, 1991.

NOVO, E. M. L. M.; BARBOSA, C. C. F.; FREITAS, R. M.; SHIMABUKURO, Y. E.; MELACK, J. M.; PEREIRA FILHO, W. Seasonal changes in chlorophyll distributions in Amazon floodplain lakes derived from MODIS images. Limnology, Springer, v. 7, n. 3, p. 153-161, 2006.

NUSH, E. A. Comparison of different methods for chlorophyll and phaeopigment determination. Archiv für Hydrobiologie, Beiheft, v. 14, p. 14-39, 1980.

PINHEIRO, M. C. N.; OIKAWA, T.; VIEIRA, J. L. F.; GOMES, M. S. V.; GUIMARAES, G. A.; CRESPO-LOPEZ, M. E. et al. Comparative study of human exposure to mercury in riverside communities in the Amazon region. Brazilian Journal of Medical and Biological Research, Ribeirão Preto, v. 39, n. 3, p. 411-414, 2006.

TELMER, K.; COSTA, M.; SIMOES ANGELICA, R.; ARAUJO, E. S.; MAURICE, Y. The source and fate of sediment and mercury in the Tapajos River, Para, Brazilian Amazon: ground- and space-based evidence. Journal of Environmental Management, London, v. 81, n. 2, p. 101-113, 2006.

VITTORIO, E. B.; DEKKER, A. G. Satellite hyperspectral remote sensing for estimating estuarine and costal water quality. IEEE Transactions on Geoscience and Remote Sensing, Piscataway, v. 41, n. 6, p. 1378-1387, 2003.

WETZEL, R. G.; LIKENS, G. E. Limnological analyses. New York: Springer-Verlag, 1991. $391 p$. 